\title{
Pop-Up Book Media on Animal Life Cycle Topic
}

\section{Ni Made Radha Dwi Goestiani ${ }^{*}$, I Made Citra Wibawa ${ }^{2}$, Ni Wayan Rati ${ }^{3}$}

1,2,3 Prodi Pendidikan Guru Sekolah Dasar, Universitas Pendidikan Ganesha, Singaraja, Indonesia

\section{ART I CLE IN F O}

Article history:

Received March 08, 2021

Revised March 11, 2021

Accepted July 30, 2021

Available online August 25, 2021

Kata Kunci:

Media, Pop-Up Book, Daur Hidup

Hewan

Keywords:

Media, Pop-Up Book, Animal Life Cycle

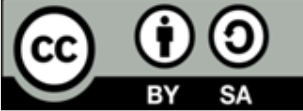

This is an open access article under the CC BY-SA license.

Copyright () 2021 by Author. Published by Universitas Pendidikan Ganesha.

\begin{abstract}
A B S T RAK
Kurangnya kreativitas guru dalam mengembangkan media pembelajaran yang sesuai dengan karakteristik siswa membuat pembelajaran menjadi kurang maksimal. Oleh karena itu perlu adanya suatu pengembangan media yang cocok dalam suatu pembelajaran. Tujuan penelitian ini untuk mengembangkan media pop-up book pada topik daur hidup hewan. Jenis penelitian ini yaitu penelitian pengembangan. Model yang digunakan adalah ADDIE. Subjek penelitian ini 1 orang ahli materi, desain, media, 2 orang praktisi, dan 5 orang siswa. Metode yang digunakan untuk mengumpulkan data yaitu observasi, wawancara, dan kuesioner. Instrument yang digunakan untuk mengumpulkan data yaitu kuesioner. Metode dan instrumen yang digunakan yaitu ranting scale. Teknik yang digunakan dalam menganalisis data yaitu analisis deskriptif kualitatif dan kuantitatif. Hasil analisis menunjukan media pop-up book yang yang dikembangkan mendapatkan kualifikasi sangat baik dari para ahli dan siswa. Jadi, media pop-up book pada topik daur hidup hewan layak untuk digunakan dalam proses pembelajaran dengan kualifikasi sangat baik. Implikasi pada penelitian ini adalah Media pop-up book dapat dimanfaatkan untuk meningkatkan pengetahuan pembelajaran IPA.
\end{abstract}

\section{A B S T R A C T}

The lack of teacher creativity in developing learning media that is by the characteristics of students makes learning less than optimal. Therefore, it is necessary to develop suitable media in learning. The purpose of this study was to develop a pop-up book on the topic of animal life cycles. This type of research is development research. The model used is ADDIE. The subject of this research is one material, design, media expert, two practitioners, and five students. The methods used to collect data are observation, interviews, and questionnaires. The instrument used to collect data is a questionnaire. The method and instrument used is the twig scale. The technique used in analyzing the data is descriptive qualitative and quantitative analysis. The analysis results show that the developed pop-up book media received excellent qualifications from experts and students. So, the pop-up book media on animal life cycles deserve to be used with excellent qualifications in the learning process. This research implies that pop-up book media can be used to increase science learning knowledge.

\section{INTRODUCTION}

Science is one of the 2013 elementary school curriculum (Gunawan et al., 2019; Hasibuan et al., 2020). This content is learned in an integrated manner with other content into a theme. Nevertheless, the learning process for science content still needs special attention (Hasibuan et al., 2020; Suryandari et al., 2018). Ideally, the science content learning process is carried out by scientific inquiry to develop students' scientific attitudes, which include: critical thinking skills, creativity, logic, initiative, good communication, and understanding of concepts that can be applied in everyday life (Permatasari, 2017; Suryantari et al., 2019; Widyanto, 2017). These abilities must be developed in children so that later students can overcome various challenges at school and in everyday life (Lavi et al., 2021; Rovers et al., 2018; Sung, 2017). Learning that prioritizes applying concepts to everyday life makes learning meaningful (Chauhan, 2017; Kenedi et al., 2018; Lian et al., 2020).

However, in reality, the learning process for science content in the field is very contrary to what is expected. The observations carried out from December 2, 2020, to December 4, 2020, at SD Gugus IX, Buleleng District, showed that the learning process for science content was still focused on teacher explanations. The use of media in the learning process can be said to be still very lacking. Furthermore, 
from the interview process, it was found that the cause of the lack of media use was the limited availability of learning media by the topics being studied. Several studies have stated that the cause of students' lack of enthusiasm in learning is due to the lack of application of models and the use of learning media (Diyantari et al., 2020; Hastuti et al., 2019; Kusumah et al., 2020). On the other hand, teachers find it challenging to present material because teachers do not use learning media (Antari et al., 2019; Pratama \& Retnawati, 2018). This is, of course very far away when compared to the ideal science learning process, namely student-centered learning and utilizing learning media by the characteristics of the material and students. If this problem is not immediately addressed, it will undoubtedly impact the decline in the quality of the science learning process and the quality of the graduates produced.

Innovation in the learning process is a must in realizing the learning process. This innovation can be started by shifting the learning paradigm from teacher-centered to student-centered (Gunawan et al., 2019; Setianingsih et al., 2019). Student-centered science learning positively affects student creativity (Huang et al., 2020; Perignat \& Katz-Buonincontro, 2019; Silberman et al., 2021). Developing a learning process centered on student activities is tantamount to building the passion and willingness of students to learn. In this effort, the teacher has a crucial role in organizing the learning process (Febriana et al., 2018). Learning media is one of the right tools in building students' passion for learning (Asrial et al., 2020; Handayani et al., 2021). Knowing a learning media and understanding how to use it can help teachers increase student activity and effectiveness during the learning process (Kurniawan et al., 2017). In addition, the use of appropriate learning media will facilitate and maximize the achievement of learning objectives (Jabri et al., 2020; Nilayanti et al., 2017).

One of the efforts that can be done to overcome the problems above is to develop learning media that can foster student enthusiasm in learning. One of the media that is considered appropriate to be developed is a pop-up book on animal life cycles in science content. Pop-up book media are media such as books complete with pictures, and some parts will move or give the impression of arising (Diyantari et al., 2020; Nikmah et al., 2019). The selection of pop-book media will increase students' enthusiasm in learning because this media is very interesting according to students' visual abilities and, of course, practical use (Mustofa \& Syafi'ah, 2018; Yuliani et al., 2020). This media is suitable for teaching very abstract concepts and requires concrete objects in its presentation (Maharani et al., 2018).

Several previous studies have developed pop-up book media and stated that pop-up book media is feasible to be developed (Dewanti et al., 2018; Hidayah et al., 2020; Khoiriyah \& Sari, 2018; Masturah et al., 2018). Furthermore, it is explained that the use of pop-up book media makes learning more effective and positively impacts student learning outcomes (Ruqoyyah et al., 2020; Yuliani et al., 2020). However, the pop-up book media developed in this study has differences from these studies. The difference lies in the topic taken, namely the life cycle of animals, and more importantly, through this media, students are invited to assemble their stages of animal metamorphosis to make the learning process more active and exciting. The purpose of this study is to produce a validated pop-up book learning media so that it is hoped that this media can improve the quality of the science learning process, especially the topic of animal life cycles, and ultimately improve student learning outcomes.

\section{METHOD}

This study aims to develop a pop-up book media on animal life cycles using the ADDIE model. In this development research, several stages are carried out, namely analysis, design, development, implementation, and evaluation. The analysis phase carried out is analyzing competence, analyzing characteristics, and analyzing the material. The curriculum analysis stage is carried out by analyzing KI, $\mathrm{KD}$, and indicators in student books to be used as a guide to developing material in media. The needs analysis stage is carried out to determine the needs of teachers and students in the learning process. Needs analysis is done by giving questionnaires to teachers and students. Furthermore, analyzing student characteristics includes analyzing students using the developed media and analyzing good media used to determine the characteristics of suitable media. The design phase focuses on three activities: the selection of materials developed in the pop-up book media, strategies, and forms of the pop-up book media design, which are then shown to the supervisor to obtain input or suggestions so that improvements can be made.

The media development stage was assessed by 2 lecturers, 2 teachers, and 5 students. The 2 lecturers are 1 lecturer as a subject expert and 1 as a design expert and learning media. For 2 teachers as respondents and 5 students as individual test subjects, the data from the expert assessment was then analyzed to determine the feasibility and improve if there were suggestions or input. The implementation phase results from the development applied by applying the media created to know the impact of the media in the learning process. We see the situation and conditions this stage cannot be carried out because it is still Covid-19 in Indonesia. Next, the last stage is to evaluate the last part. The evaluation was carried out to determine whether the developed media affected learning outcomes and quality in the 
learning process. We see the situation and conditions. This stage cannot be carried out because if it is still Covid-19 in Indonesia.

The subjects in this study were 1 person as a material expert, 1 person as a design expert and media expert, 2 people as practitioners, and 5 students as respondents. In comparison, the object of this research is the validity of the pop-up book media on the topic of animal life cycles in elementary schools. Furthermore, the data collection method was carried out by the questionnaire method, namely by providing a list of questions or statements to the respondents. While the instrument used is a rating scale of 1-4 (Ilhami \& R, 2017). To ensure the instrument's validity, it must go through several stages: 1) creating a grid table, 2) consulting with the supervisor, 3) compiling the instrument. The media validity sheet instrument grid includes 6 aspects, namely cover aspects, format, content, language, practicality, and effectiveness (Rahayu \& Festiyed, 2018).

Table 1. Grid for Preparation of Material Expert Review Instruments

\begin{tabular}{cl}
\hline Aspect & \multicolumn{1}{c}{ Indicator } \\
\hline Curriculum & The suitability of the material with the Basic Competence \\
& The suitability of the material with the indicator \\
& Retention of material \\
& The breadth and depth of the material \\
& The material is in accordance with the student's cognitive \\
& Interesting material \\
& Material systematics \\
& Image selection accuracy \\
& Image clarity \\
Visualisasi & Language compatibility \\
& Clarity of language use \\
Bahasa & Correct use of punctuation \\
& Evaluation suitability \\
& The suitability of the level of difficulty of the question \\
\hline
\end{tabular}

Table 2. Grid of Design Expert Review Instruments

\begin{tabular}{cl}
\hline Aspect & \multicolumn{1}{c}{ Indicator } \\
\hline Visualization & The attractiveness of the media display \\
& Media design builds student learning motivation \\
Curriculum & The suitability of the material with KD, \\
& The suitability of the material with the indicator \\
Material Presentation & Systematic presentation of material \\
& Clarity of material description \\
& attractiveness \\
& Submission of materials \\
& Giving examples \\
Text & Text clarity \\
& Font size \\
Evaluation & Question suitability \\
\hline
\end{tabular}

Table 3. Grid for the Preparation of Media Expert Review Instruments

\begin{tabular}{cl}
\hline Aspect & Indicator \\
\hline Appearance & Attractiveness \\
& Suitability with student characteristics \\
& proportional size \\
& Motivate students \\
Text & Font size \\
& Font type \\
& Text legibility \\
& Image compatibility \\
Picture & Image clarity \\
& Color selection \\
Color & Color clarity \\
& The layout of the components on each page is harmonious \\
\hline
\end{tabular}


The instruments that have been prepared are then carried out at the validity test stage. A validity test was conducted to determine the level of validity of the instrument using the Gregory formula. After the data is collected using the instrument, the next step will be to analyze qualitative descriptive analysis techniques and quantitative descriptive analysis. Qualitative data is data obtained at the expert review stage in the form of suggestions and comments. Then from the data, improvements are made to the developed media by the suggestions and comments given so that it becomes a better media. While quantitative data is data obtained at the expert review stage in the form of scores on the assessment sheet, the data is calculated on average using the mean formula to obtain the results of the validity of the developed media. After the average is obtained, it is converted to a conversion table for the level of achievement on a scale of 5 .

\section{RESULT AND DISCUSSION}

\section{Result}

The development of pop-up book media on animal life cycles in grade IV Elementary School through several procedures, namely: analysis, design, and development. The analysis stage goes through several stages: needs analysis, curriculum analysis, student characteristics analysis, and good media analysis. Based on the questionnaire results, $100 \%$ of teachers stated that using learning media was very important to use on the topic of the animal life cycle in teaching. 88\% of teachers stated that when teaching, teachers use learning media other than books. $100 \%$ of teachers stated that they did not use learning media in the form of pop-up books in the learning process. $100 \%$ stated that the pop-up book media is essential to be developed. From this, a solution was obtained that the pop-up book learning media on animal life cycles is very good to be developed. Curriculum analysis is carried out by analyzing $\mathrm{KI}, \mathrm{KD}$, and indicators contained in teacher and student books used as the basis for developing media.

The following stage designs. Making pop-up book media begins with designing a design using Photoshop CS6, then printing and binding manually. The developed pop-up book has an A4 paper size of $21 \mathrm{~cm} \times 29.7 \mathrm{~cm}$ with a total of 32 pages, including the front cover and back cover. The thick paper helps maintain the durability of the media. These types of paper are glossy and art paper. In the end, it contains practice questions that are arranged to know the students' abilities after using the help of a pop-up book. The development stage is developing Pop Up media. The media consists of cover, essential competencies and indicators, table of contents, content section, practice questions, and answer keys. The examples of the results of the development of pop-up book media are as follows figure 1.

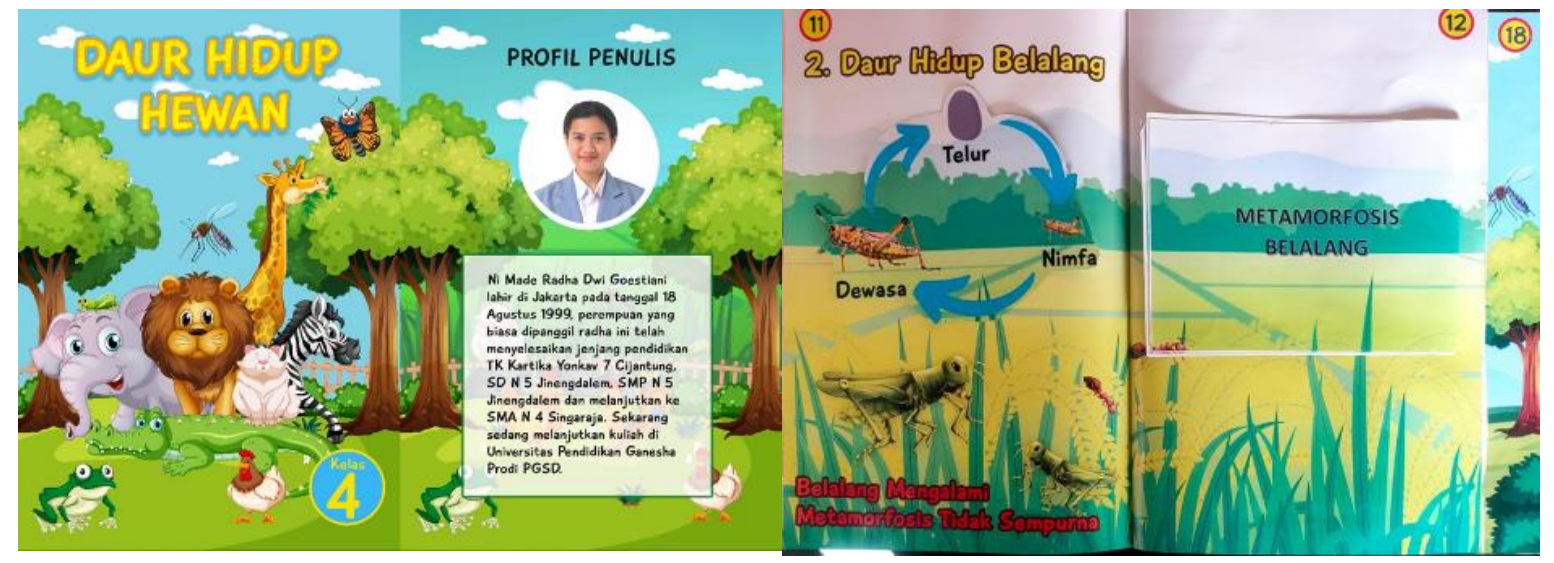

Figure 1. Pop-up Book Media Display

The data obtained on the media assessment sheet was then analyzed to determine the validity of the media. The validity of the pop-up book media content on the topic of the animal life cycle obtained high validity criteria, and the respondent's validity obtained a very good category. These results were obtained from the results of the validity score of the pop-up book media on the topic of the animal life cycle in the validity index analysis. The assessment of learning material experts got a score of 0.89 with the criteria of "high validity." The essential competencies and indicators are conveyed clearly in the popup book media, and from the delivery of material on the pop-up book media can attract students' interest in learning. A score of 0.90 from the results of the assessment of learning design experts with the criteria of "high validity". This is because the design of the images displayed with the material being studied is appropriate and the suitability of the material on the pop-up book media is well organized and the layout 
of the text displayed on the pop-up book media is compatible. And a score of 0.91 from the results of the assessment of learning media experts with the criteria of "high validity". This is because the design of the images/colors displayed with the material being studied is appropriate and the layout of the components on each page on the pop-up book media is well organized and the font sizes displayed on the pop-up book media are compatible. If the experts' assessment scores are converted into the Aiken validity index criteria, each score falls into the range with the "High Validity" criteria. Supported by the results of the respondents' assessment of the pop-up book media that has been analyzed using the Mean formula, a score of 4.85 is obtained from the practitioner's response and a score of 4.80 is the result of the student response. The results of the respondents got the category "Very Good". This is because the presentation of material on the pop-up book media makes students listen well and the material presented in the pop-up book media for students is important. If the respondents' assessment scores are converted into a fivescale conversion, then the average of each score falls into the range of 4.00 to 5.01 with the "Very Good" category. Pop-up book media can foster student interest in learning. This is evidenced from the results of product trial data that have been carried out that the pop-up book media on the animal life cycle is declared "Valid" to assist teachers in carrying out learning.

\section{Discussion}

According to constructivism theory, knowledge is not given from nature, but knowledge is the result of active human construction itself, so it must be done directly by students who are obtained through direct experience (Barlia, 2011; Kusmariyatni, 2020). This is adjusted in the use of media students who are directly involved, namely by folding, opening, and reading what is in the pop-up book media (Baiduri et al., 2019; Sentarik \& Kusmariyatni, 2020). Using these media can provide experience to students, so they will better understand the material being studied (Diyantari et al., 2020; Sari \& Azzah, 2017). The developed pop-up book media on animal life cycles can also motivate student learning and facilitate students with visual and kinesthetic learning styles. Learning with a visual style will make students learn by seeing, gazing, and observing the object being studied to make it easier to understand the material being studied. While learning using a kinesthetic style is more likely for students to learn to do it with physical activity (Ulia \& Sari, 2017; Wahyuni, 2017).

Pop-up book media can be used in the learning process to stimulate students to be motivated to participate in the learning process. Good media will increase students' learning motivation (Anwariningsih \& Ernawati, 2013; Knoop-van Campen et al., 2020). Therefore, the pop-up book media on the topic of animal life cycles in grade IV elementary school is very suitable to be developed based on the needs analysis that has been done. In addition, the media developed were designed using attractive colors and images adapted to the characteristics of students and adapted to the topic of the animal life cycle. The suitability of colors and images in the media will make it easier for students to understand the subject matter (Kamelia, 2019; Sargeant, 2015). To find out students' understanding after using the media, there are practice questions at the end. Practice questions will determine students' understanding (Bdiwi et al., 2019; Ulya et al., 2019).

The use of pop-up book media on the topic of animal life cycles in grade IV elementary schools is suitable for optimizing students' understanding of the material (Dewanti et al., 2019; Khoiriyah \& Sari, 2018; Ningtiyas et al., 2019). Therefore, the pop-up book media at the fourth-grade elementary school level on the topic of the animal life cycle is a means that can influence students, especially knowledge on student learning outcomes which is increasing. ADDIE has clear and systematic stages of learning development (Cahyadi, 2019; Harjanta \& Herlambang, 2018). The media design that has been done is made using Photoshop CS6, then printed, followed by the binding process, which is done manually. This is done so that the media that will be used becomes practical and colorful so that later it will be able to motivate students in learning. The developed pop-up book media can facilitate both learning styles. Students who study with visual and kinesthetic styles can observe every material contained in the media and open exciting pages on the pop-up book media to provide a meaningful learning experience for students.

The advantages of the media that have been developed are that they can clarify the presentation of messages and information to facilitate and improve learning processes and outcomes. This research implies that the pop-up book media created for the fourth-grade elementary school level on the animal life cycle is categorized as a perfect medium, which is the implication obtained from this research. This popup book media can increase knowledge of science learning, especially on the topic of animal life cycles. The pop-up book media was developed to be suitable for optimizing the understanding of the material for students in the fourth grade of elementary school. Students need actual or concrete means to increase the knowledge they want to achieve. Through the development of pop-up book media products, students can be facilitated in their learning to achieve learning objectives. 


\section{CONCLUSION}

The pop-up book media that was developed got excellent qualifications so that it was feasible to be used in the learning process. Pop-up book media on the topic of animal life cycles is a means that can influence students, especially knowledge on increasing student learning outcomes.

\section{REFERENCES}

Antari, N. L. G. S., Pudjawan, K., \& Wibawa, I. M. C. (2019). Pengaruh Model Pembelajaran Kooperatif Tipe Course Review Horay Berbantuan Media Gambar Terhadap Hasil Belajar IPA. International Journal of Elementary Education, $3(2), \quad$ 116-123. https: //doi.org/http://dx.doi.org/10.23887/ijee.v3i2.18512.

Anwariningsih, \& Ernawati. (2013). Development of Interactive Media for ICT Learning at Elementary School based on Student Self Learning. Journal of Education and Learning, 7(2), 121-128. https://doi.org/10.11591/edulearn.v7i2.226.

Arsanti, M. (2018). Pengembangan bahan ajar mata kuliah penulisan kreatif bermuatan nilai-nilai pendidikan karakter religius bagi mahasiswa prodi PBSI, FKIP. Unissula. Kredo: Jurnal Ilmiah Bahasa Dan Sastra, 1(2), 69-88. https://doi.org/https://doi.org/10.24176/kredo.v1i2.2107.

Asrial, Syahrial, Maison, Kurniawan, D. A., \& Piyana, S. O. (2020). Ethnoconstructivism E-Module to Improve Perception, Interest, and Motivation of Students in Class V Elementary School. JPI (Jurnal Pendidikan Indonesia), 9(1), 30-41. https://doi.org/10.23887/jpi-undiksha.v9i1.19222.

Baiduri, Marhan, \& Lufita. (2019). Pengembangan media pembelajaran pop-up book berbasis audio pada materi bangun datar segiempat. Jurnal Program Studi Pendidikan Matematika, 8(1). https://doi.org/10.24127/ajpm.v8i1.1951.

Barlia, L. (2011). Konstruktivisme dalam pembelajaran sains Tinjauan Epistemologi, Ontologi, Dan Keraguan Dalam Praksisnya. Cakrawala Pendidikan, 3(30), 343-358. https://journal.uny.ac.id/index.php/cp/article/view/4200/pdf.

Bdiwi, R., de Runz, C., Faiz, S., \& Cherif, A. A. (2019). Smart learning environment: Teacher's role in assessing classroom attention. Research in Learning Technology, 27, 1-14. https://doi.org/10.25304/rlt.v27.2072.

Cahyadi, R. A. H. (2019). Pengembangan bahan ajar berbasis ADDIE model. Halaqa: Islamic Education Journal, 3(1), 35-42. https://doi.org/https://doi.org/10.21070/halaqa.v3i1.2124.

Chauhan, S. (2017). A meta-analysis of the impact of technology on learning effectiveness of elementary students. Computers \& Education, 105, 14-30. https: //doi.org/10.1016/j.compedu.2016.11.005.

Dewanti, H., Toenlioe, A. J., \& Soepriyanto, Y. (2019). Pengembangan Media Pop-Up Book Untuk Pembelajaran Lingkungan Tempat Tinggalku Kelas Iv Sdn 1 Pakunden Kabupaten Ponorogo. $\begin{array}{llll}\text { Jurnal Kajian Teknologi } & \text { Pendidikan, }\end{array}$ http://journal2.um.ac.id/index.php/jktp/article/view/4551.

Diyantari, I. A. K. D., Wiyasa, N., \& Manuaba, S. (2020). Model Snowball Throwing Berbantuan Media Pop Up Book Berpengaruh Terhadap Kompetensi Pengetahuan Ipa. Jurnal Ilmiah Pendidikan Profesi Guru, 3(1), 9-21. https://doi.org/10.23887/jippg.v3i1.26973.

Febriana, M., 'ari, H. A. A., Subali, B., \& Rusilowati, A. (2018). Penerapan model pembelajaran Inquiry Pictorial Riddle untuk meningkatkan keaktifan siswa. (JPFK), Jurnal Pendidikan Fisika Dan Keilmuan, 4(1). https://doi.org/http://doi.org/10.25273/jpfk.v4i1.1879.

Gunawan, Harjono, A., Hermansyah, \& Herayanti, L. (2019). Guided inquiry model through virtual laboratory to enhance students' science process skills on heat concept. Cakrawala Pendidikan, 38(2), 259-268. https://doi.org/10.21831/cp.v38i2.23345.

Handaruni Dewanti, Anselmus J E Toenlioe, Y. S. (2018). Pengembangan media Pop-Up Book untuk Pembelajaran Lingkungan Tempat Tinggalku Kelas IV SDN 1 Pakuaden Kabupaten Ponorogo. Jurnal Kajian Teknologi Pendidikan, 221-228. http://journal2.um.ac.id/index.php/jktp/article/view/4551/3408.

Handayani, D., Elvinawati, E., Isnaeni, I., \& Alperi, M. (2021). Development Of Guided Discovery Based Electronic Module For Chemical Lessons In Redox Reaction Materials. International Journal of Interactive Mobile Technologies (IJIM), 15(07), 94. https://doi.org/10.3991/ijim.v15i07.21559.

Harjanta, A. T. J., \& Herlambang, B. A. (2018). Rancang Bangun Game Edukasi Pemilihan Gubernur Jateng Berbasis Android Dengan Model ADDIE. Jurnal Transformatika, 16(1), 91-97. https: //doi.org/10.26623/transformatika.v16i1.894.

Hasibuan, M. H. E., Fuldiaratman, F., Dewi, F., Sulistiyo, U., \& Hindarti, S. (2020). Jigsaw Learning Strategy In A Diverse Science-Classroom Setting: Feasibility, Challenges, And Adjustment. Cakrawala 
Pendidikan, 39(3). https://doi.org/10.21831/cp.v39i3.30634.

Hastuti, H. W., Baedowi, S., \& Mushafanah, Q. (2019). Keefektifan Model Pembelajaran Numbered Heads Together Berbantu Media Panelpa (Papan Flanel IPA) Terhadap Hasil Belajar. International Journal of Elementary Education, 3(2), 108-115. https://doi.org/10.23887/ijee.v3i2.18513.

Hidayah, N., Wahyuni, R., \& Hasnanto, A. T. (2020). Pengembangan Media Pembelajaran Gambar Berseri Berbasis Pop-Up Book Untuk Meningkatkan Keterampilan Menulis Narasi Bahasa Indonesia. Jurnal Pendidikan Dan Pembelajaran Dasar, 7(1). https://doi.org/10.24042/terampil.v7i1.6182.

Huang, S.-Y., Kuo, Y.-H., \& Chen, H.-C. (2020). Applying Digital Escape Rooms Infused with Science Teaching in Elementary School: Learning Performance, Learning Motivation, and Problem-Solving Ability. Journal Pre-Proof, 1-46. https://doi.org/10.1016/j.tsc.2020.100681.

Ilhami, R. S., \& R, D. (2017). Penilaian Kinerja Karyawan dengan Metode AHP dan Rating Scale. Jurnal Optimasi Sistem Industri, 16(2). https://doi.org/10.25077/josi.v16.n2.p150-157.2017.

Jabri, U., Sukaryadi, A., Andika, Amin, S. Y., Arni, Pairi, M. S., Faika, N., M, N. I., Supri, Yuneda, Mahmud, Misna, Sumi, Rosminah, \& Elihami. (2020). Media Pembelajaran Pop Up Book Kelas V SDN 181 Curio Yang Kreatif Dan Inovatif. Maspul Journal of Community Empowerment, 2(2), 34-39. https://ummaspul.e-journal.id/pengabdian/article/view/784/366.

Kamelia, K. (2019). Using Video as Media of Teaching in English Language Classroom: Expressing Congratulation and Hopes. Utamax : Journal of Ultimate Research and Trends in Education, 1(1), 34-38. https://doi.org/10.31849/utamax.v1i1.2742.

Karisma, I. K. E., Margunayasa, I. G., \& Prasasti, P. A. T. (2020). Media Pop-Up Book pada Topik Perkembangbiakan Tumbuhan dan Hewan Kelas VI Sekolah Dasar. Jurnal Ilmiah Sekolah Dasar, 4(2), 121-130. https://doi.org/10.23887/jisd.v4i2.24458.

Kenedi, A. K., Hendri, S., Ladiva, H. B., \& Nelliarti. (2018). Kemampuan Koneksi Matematis Siswa Sekolah Dasar Dalam Memecahkan Masalah Matematika. Jurnal Numeracy, 5(2), 226-235. https://doi.org/10.46244/numeracy.v5i2.396.

Khoiriyah, E., \& Sari, E. Y. (2018). Pengembangan Media Pembelajaran Pop-Up Book Pada Mata Pelajaran IPA Kelas III SDN 3 Junjung Kecamatan Sumbergempol Kabupaten Tulungagung Tahun Ajaran 2017/2018. Jurnal Bidang Pendidikan Dasar (JBPD), 2(2), 22-32. https://ejournal.unikama.ac.id/index.php/JBPD/article/view/2495.

Knoop-van Campen, C. A. N., Segers, E., \& Verhoeven, L. (2020). Effects of audio support on multimedia learning processes and outcomes in students with dyslexia. Computers and Education, 150(February), 103858. https://doi.org/10.1016/j.compedu.2020.103858.

Kurniawan, Dian, \& Dewi, S. V. (2017). Pengembangan perangkat pembelajaran dengan media screencasto-matic mata kuliah kalkulus 2 menggunakan model 4-d thiagarajan. Jurnal Siliwangi, 3(1). https://doi.org/10.37058/jspendidikan.v3i1.193.

Kusmariyatni, N. (2020). Media Pop-Up Book pada Topik Sistem Tata Surya Kelas VI Sekolah Dasar. Jurnal Ilmiah Sekolah Dasar, 4(2), 197-208. https://doi.org/10.23887/jisd.v4i2.25135.

Kusumah, R. G. T., Walid, A., Pitaloka, S., Dewi, P. S., \& Agustriana, N. (2020). Penerapan Metode Inquiry Untuk Meningkatkan Hasil Belajar Materi Penggolongan Hewan Di Kelas IV SD Seluma. Jurnal Pendidikan Matematika Dan IPA, 11(1), 142-153. https://doi.org/10.26418/jpmipa.v11i1.34708.

Lavi, R., Tal, M., \& Dori, Y. J. (2021). Perceptions of STEM alumni and students on developing 21st century skills through methods of teaching and learning. Studies in Educational Evaluation, 70, 1-11. https: //doi.org/10.1016/j.stueduc.2021.101002.

Lian, B., Kristiawan, M., Ammelia, D., Primasari, G., Anggung, M., \& Prasetyo, M. (2020). Teachers' Model in Building Students' Character. Journal of Critical Reviews, 7(14), 927-932. https: //doi.org/10.31838/jcr.07.14.165.

Maharani, H. R., Ubaidah, N., \& Aminudin, M. (2018). Efektifitas Model Concept Attainment Ber-Budaya Akademik Islami Berbantuan Pop-Up Book pada Materi Bangun Ruang Sisi Datar. Kreano: Jurnal Matematika Kreatif-Inovatif, 9(1), 100-106. https://doi.org/10.15294/kreano.v9i1.12693.

Masturah, E. D., Mahadewi, L. P. P., \& Simamora, A. H. (2018). Pengembangan Media Pembelajaran Pop-Up Book pada Mata Pelajaran IPA Kelas III Sekolah Dasar. Jurnal EDUTECH Universitas Pendidikan Ganesha, 6(2), 212-221. https://doi.org/10.23887/jeu.v6i2.20294.

Mustofa, R., \& Syafi'ah, R. (2018). Pengembangan Media Pembelajaran Pop Up Book Materi Kenampakan Permukaan Bumi Mata Pelajaran IPA Kelas III SD. ELSE (Elementary School Education Journal), 2, 30-41. https://doi.org/http://dx.doi.org/10.30651/else.v2i2.1723.

Nikmah, S., Nuroso, H., \& Reffiane, F. (2019). Pengaruh Model Pembelajaran Terpadu Tipe Shared Berbantu Media Pop- Up Book Terhadap Hasil Belajar. Jurnal Pedagogi Dan Pembelajaran, 2(2), 264. https://doi.org/10.23887/jp2.v2i2.17920.

Nilayanti, P. M., Putra, I. K. A., \& Suadnyana, I. N. (2017). Pengaruh Model Pembelajaran Kooperatif Tipe 
Number Head Together Berbantuan Media Konkret Terhadap Kompetensi Pengetahuan Ipa Siswa Kelas IV SD Gugus Kompyang Sujana Denpasar Utara. Mimbar PGSD, 5(3), 1-9. https: //doi.org/10.23887/jjpgsd.v5i2.10781.

Ningtiyas, T. W., Setyosari, P., \& Praherdiono, H. (2019). Pengembangan Media Pop-Up Book untuk Mata Pelajaran IPA Bab Siklus Air dan Peristiwa Alam sebagai Penguatan Kognitif Siswa. Jurnal Kajian Teknologi Pendidikan, 2(2), 115-120. https://doi.org/10.17977/um038v2i22019p115.

Perignat, E., \& Katz-Buonincontro, J. (2019). STEAM in practice and research: An integrative literature review. Thinking Skills and Creativity, 31,31-43. https://doi.org/10.1016/j.tsc.2018.10.002.

Permatasari, N. E. (2017). Peningkatan Hasil Belajar IPA Siswa Kelas 5 SD Menggunakan Model Pembelajaran Kooperatif Tipe TGT Berbantuan Media Gambar. Jurnal Pendidikan Sekolah Dasar (JPsd), 2(3), 96-104. https://doi.org/10.30870/jpsd.v3i2.2131.

Pratama, G. S., \& Retnawati, H. (2018). Urgency of Higher Order Thinking Skills (HOTS) Content Analysis in Mathematics Textbook. Journal of Physics: Conference Series, 1097(1). https://doi.org/10.1088/1742-6596/1097/1/012147.

Rahayu, C., \& Festiyed, F. (2018). Validitas Perangkat Pembelajaran Fisika SMA Berbasis Model Pembelajaran Generative Dengan Pendekatan Open-Ended Problem Untuk Menstimulus Keterampilan Berpikir Kritis Peserta Didik. JPF (Jurnal Pendidikan Fisika) Universitas Islam Negeri Alauddin Makassar, 7(1), 1-6. https://doi.org/10.24252/jpf.v7i1.5363.

Rovers, S. F. E., Clarebout, G.Rovers, S. F. E., Clarebout, G., Savelberg, H. H. C. M., \& van Merriënboer, J. J. G. (2018). Improving student expectations of learning in a problem-based environment. Computers in Human Behavior, 87, 416-423. https://doi.org/10.1016/j.chb.2018.02.016.

Savelberg, H. H. C. M., \& van Merriënboer, J. J. G. (2018). Improving student expectations of learning in a problem-based environment. Computers in Human Behavior, 87, 416-423. https://doi.org/10.1016/j.chb.2018.02.016.

Ruqoyyah, R., Fatkhurrohman, M. A., \& Arfiani, Y. (2020). Implementasi Model Inkuiri Terbimbing Berbantuan Pop-up book untuk Meningkatkan Kemampuan Berpikir Kreatif Peserta Didik. JEMS: Jurnal Edukasi Matematika Dan Sains, 8(1), 42-48. https://doi.org/10.25273/jems.v8i1.6166.

Sargeant, B. (2015). What is an ebook? What is a Book App? And Why Should We Care? An Analysis of Contemporary Digital Picture Books. Children's Literature in Education, 46(4), 454-466. https: //doi.org/10.1007/s10583-015-9243-5.

Sari, A. S., \& Azzah, U. (2017). The Development of Pop-up Book on the Role of Buffer in the Living Body. European Journal of Social Sciences Education and Research, 4(4), 213-221. http://journals.euser.org/index.php/ejser/article/view/2430.

Sentarik, K., \& Kusmariyatni, N. (2020). Media Pop-Up Book pada Topik Sistem Tata Surya Kelas VI Sekolah Dasar. Jurnal Ilmiah Sekolah Dasar, 4(2), 197. https://doi.org/10.23887/jisd.v4i2.25135.

Setianingsih, I. G. A. A. A., Putra, D. K. N. S., \& Kt.Ardana, I. (2019). Pengaruh Model Pembelajaran Reciprocal Teaching Berbantuan Media Audio Visualterhadap Kompetensi Pengetahuan IPA. Journal of Education Technology, 3(3), 203-209. https://doi.org/10.23887/jet.v3i3.21827.

Silberman, D., Carpenter, R., Takemoto, J. K., \& Coyne, L. (2021). The impact of team-based learning on the critical thinking skills of pharmacy students. Currents in Pharmacy Teaching and Learning, 13(2), 116-121. https://doi.org/10.1016/j.cptl.2020.09.008.

Sudarma, I. K., Angga, P. M. W., \& Suartama, I. K. (2020). E-Komik Pendidikan Untuk Membentuk Karakter Dan Meningkatkan Hasil Belajar Siswa Kelas V Pada Mata Pelajaran Bahasa Indonesia. Jurnal Edutech Undiksha, 8(2), 93-106. https://doi.org/10.23887/jeu.v8i2.28920.

Sung, E. (2017). The influence of visualization tendency on problem-solving ability and learning achievement of primary school students in South Korea. Thinking Skills and Creativity, 26, 168175. https://doi.org/10.1016/j.tsc.2017.10.

Suryandari, Sajidan, Rahardjo, Prasetyo, \& Fatimah. (2018). Project-Based Science Learning And PreService Teachers' Science Literacy Skill And Creative Thinking. Cakrawala Pendidikan, 37(3). https://doi.org/10.21831/cp.v38i3.17229.

Suryantari, N. M. A., Pudjawan, K., \& Wibawa, I. M. C. (2019). Pengaruh Model Pembelajaran Inkuiri Terbimbing Berbantuan Media Benda Konkret Terhadap Sikap Ilmiah dan Hasil Belajar IPA. International Journal of Elementary Education, 3(3), 316-326. https: //doi.org/10.23887/ijee.v3i3.19445.

Ulia, N., \& Sari, Y. (2017). Pembelajaran visual, auditory dan kinestetik terhadap keaktifan dan pemahaman konsep matematika siswa sekolah dasar. Al Ibtida: Jurnal Pendidikan Guru MI, 5(2), 175-190. https://doi.org/10.24235/al.ibtida.snj.v5i2.2890.

Ulya, H., Rahayu, R., \& Riyono, A. (2019). Integration Of Products Assessment in Mind Mapping Learning to Enhance Mathematical Communication. Journal of Physics: Conference Series, 1175(012142), 1-8. 
https://doi.org/10.1088/1742-6596/1175/1/012142.

Wahyuni, Y. (2017). Identifikasi gaya belajar (visual, auditorial, kinestetik) mahasiswa pendidikan matematika. JPPM (Jurnal Penelitian Dan Pembelajaran Matematika), 10(2). https://doi.org/10.30870/jppm.v10i2.2037.

Widyanto, P. (2017). Penerapan Metode Pembelajaran Group Investigation Berbantuan Media Flanelgraf Untuk Meningkatkan Minat Dan Hasil Belajar Siswa Pada Mata Pelajaran IPA. Jurnal Pendidikan Dasar Nusantara, 3(1), 118-129. https://ojs.unpkediri.ac.id/index.php/pgsd/article/view/708.

Yuliani, F., Herman, \& Tarmizi, P. (2020). Pengaruh Model Discovery Learning Berbantuan Media Pop-Up Book terhadap Hasil Belajar Tematik Siswa Kelas IV SD Gugus X Kota Bengkulu. Jurnal Riset Pendidikan Dasar, 3(1), 1-8. https://doi.org/10.33369/juridikdas.3.1.1-8. 